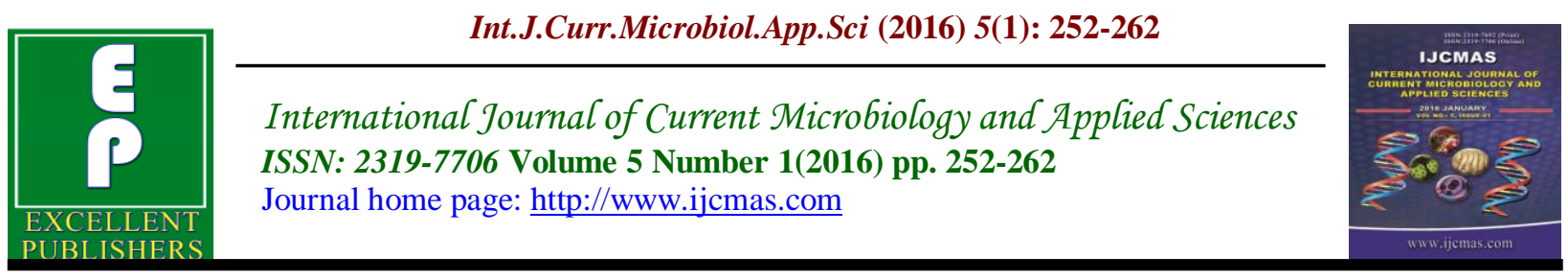

Original Research Article

http://dx.doi.org/10.20546/ijcmas.2016.501.024

\title{
Biophysical and Biochemical Factors of Resistance in Tomato Accessions as Influenced by Selected Bioinoculants against Fruit Worm Helicoverpa armigera (Hubner)
}

\author{
N. Muthukumaran* \\ Department of Entomology, Faculty of Agriculture, Annamalai University, \\ Annamalai Nagar 608 002, Tamil Nadu, India
}

*Corresponding author

\begin{abstract}
A B S T R A C T
Keywords

Tomato,

Microbial

inoculants,

Induced

resistance,

H.armigera.

Article Info

Accepted:

12 December 2015

Available Online:

Tomato (Lycopersicon esculentum. Mill) is an important and most popular vegetable crop worldwide. Among the various insect pests responsible for lowering the yield of tomato, the fruitworm, Helicoverpa armigera (Hubner) is a highly destructive pest causing serious damage. The present study was undertaken to analyse the role of certain microbial inoculants in enhancing insect resistance and in the selected tomato accession with the objective, to study the biochemical and biophysical factors of resistance against the fruit worm, H. armigera as influenced by microbial inoculants. Among the various microbial inoculants treatments, Pseudomonas + K-solubilizer (T9) nourished plants had higher biochemical and biophsical factors of resistance against $H$. armigera.
\end{abstract}

January 2016

\section{Introduction}

Tomato (Lycopersicon esculentum Mill.) is one of the important and remunerative vegetable crops grown around the world for fresh market and processing. The production and productivity of the crop is greatly hampered by the fruit borer, Helicoverpa armigera (Hübner) which causes damage to the developing fruits and results in yield loss ranging from 20 to 60 . The indiscriminate use of synthetic chemical pesticides to control this pest resulted in development of resistance (Armes et al., 1992) and harmful pesticide residues in fruits. To avoid such problems caused due to indiscriminate use of insecticides, utilization of Host Plant Resistance (HPR) is an ecologically viable, alternate insect pest management strategy. In the absence of natural resistance in the gene pool of crop plants or lack of desirable yield attributes in the identified insect tolerant/ resistant crop varieties, inducing resistance by manipulation of plant nutrients may be 
attempted (Muthukumaran and Selvanarayanan, 2010).

Various biophysical factors in crop plants, either in the popular cultivars or the wild relatives play a major role in conferring resistance against pests and diseases. In tomato, glandular or non glandular trichomes are generally present with much diversity that offers resistance against many pest species. Similarly, other factors like vine size, leaf lamellar factors, fruit toughness etc., might either attract or deter the pests.

The biochemical constitution of any crop or variety would exert a definite influence over the pest species either by luring or deterring or by supporting or inhibiting growth and development through synergism or antibiosis. Keeping this in mind, the present study was undertaken to analyse the role of certain microbial inoculants in enhancing biophysical and bio chemical factors of resistance in the selected tomato accessions against $H$.armigera

\section{Materials and Methods}

\section{Source of Tomato Accessions}

One tomato accession Varusanadu Local identified earlier (Selvanarayanan, 2000) as tolerant to fruit worm, Helicoverpa armigera at the Department of Entomology, Annamalai University was used for studying the resistance potentials as induced by various microbial inoculants for comparison, a popular cultivar, PKM1 was also used.

\section{Raising of Tomato Plants}

For pot culture studies, the test plants were maintained in earthen pots of $30 \mathrm{~cm}$ high and $30 \mathrm{~cm}$ dia. Pots were filled with the potting mixture comprising two parts of soil and one part of sand. Then the seeds were irrigated regularly. Twenty five days old seedlings were transplanted either in pots @ one seedling per pot or in the field and were maintained for further studies.

\section{Selection of Promising Treatments}

From the group of microbial inoculants, the promising treatments were selected. Five microbial inoculants were selected for further field evaluation and in depth studies on bases of resistance. The details on the applications of the five selected microbial inoculants are furnished below.

\begin{tabular}{|c|c|c|c|c|}
\hline $\begin{array}{l}\text { S. } \\
\text { No } \\
\end{array}$ & Treatments & $\begin{array}{c}\text { Dosage / } \\
\text { Pot } \\
\end{array}$ & $\begin{array}{c}\text { Day of } \\
\text { application }\end{array}$ & $\begin{array}{r}\text { Method of } \\
\text { application }\end{array}$ \\
\hline 1. & $\begin{array}{l}\text { Pseudomonas } \\
\text { (T3) }\end{array}$ & $200 \mathrm{mg}$ & $\begin{array}{l}\text { On the day of } \\
\text { transplanting }\end{array}$ & Soil \\
\hline 2. & $\begin{array}{l}\mathrm{K}-\text { solubilizer } \\
(\text { F. aurentia }) \\
(\mathrm{T} 4)\end{array}$ & $\begin{array}{l}3 \mathrm{ml} / \mathrm{kg} \\
\text { of seed }\end{array}$ & $\begin{array}{c}\text { One day } \\
\text { before sowing }\end{array}$ & $\begin{array}{c}\text { Seed } \\
\text { treatment }\end{array}$ \\
\hline 3. & $\begin{array}{l}\text { Azospirillum }+ \\
\mathrm{K}-\text { solubilizer } \\
(F . \text { aurentia }) \\
(\mathrm{T} 7)\end{array}$ & $\begin{array}{l}200 \mathrm{mg} \\
+3 \\
\mathrm{ml} / \mathrm{kg} \text { of } \\
\text { seed }\end{array}$ & $\begin{array}{l}\text { On the day of } \\
\text { transplanting } \\
\text { and One day } \\
\text { before sowing }\end{array}$ & $\begin{array}{c}\text { Soil }+ \text { Seed } \\
\text { treatment }\end{array}$ \\
\hline 4. & $\begin{array}{l}\text { Pseudomonas }+ \\
\mathrm{K}-\text { solubilizer } \\
\text { (F. aurentia) } \\
\text { (T9) }\end{array}$ & $\begin{array}{l}200 \mathrm{mg} \\
+3 \\
\mathrm{ml} / \mathrm{kg} \text { of } \\
\text { seed }\end{array}$ & $\begin{array}{l}\text { On the day of } \\
\text { transplanting } \\
\text { and One day } \\
\text { before sowing }\end{array}$ & $\begin{array}{c}\text { Soil }+ \text { Seed } \\
\text { treatment }\end{array}$ \\
\hline 5 & $\begin{array}{l}\text { Phosphobacteria } \\
+\mathrm{K}-\text { solubilizer } \\
(F . \text { aurentia }) \\
\text { (T10) }\end{array}$ & $\begin{array}{c}200 \mathrm{mg} \\
+3 \\
\mathrm{ml} / \mathrm{kg} \text { of } \\
\text { seed }\end{array}$ & $\begin{array}{l}\text { On the day of } \\
\text { transplanting } \\
\text { and One day } \\
\text { before sowing }\end{array}$ & $\begin{array}{c}\text { Soil }+ \text { Seed } \\
\text { treatment }\end{array}$ \\
\hline
\end{tabular}

Evaluation of Bio Physical Factors of Resistance in the Tomato Accessions as Influenced by Selected Microbial Inoculants

Biophysical factors of resistance, such as density of leaf length and breadth, leaf angle to stem were estimated. Thirty such observations were made for each treatment.

\section{Trichome Density}


Density of trichomes present in the abaxial and adaxial surfaces of the leaf and on the petiole was estimated. One $\mathrm{mm}$ long transverse section was cut from the leaf and petiole of the accessions. Then the sectioned sample was placed transversely on a clean glass slide and the number of trichomes were counted using a, binocular microscope and expressed as trichomes density per $\mathrm{mm}$ length.

\section{Leaf Length and Breadth}

Third, fifth and seventh leaf from the top of each plant were selected and their length and breadth was measured and their mean value was arrived at.

\section{Petiole Length}

Length of the petiole of third, fifth and seventh leaf from top of plant in each treatment was measured and the mean value was computed.

\section{Leaf Angle}

Leaf angle between the petiole of the leaf and the stem was measured in third, fifth and seventh leaf from the top of the plant and the mean angle was calculated.

\section{Bio-Chemical Factors of Resistance in the Tomato Accessions as Influenced by Selected Microbial Inoculants}

With a view to a ascertain the biochemical factors of resistance in the test plants, the following biochemical constituents were analyzed.

\section{Estimation of Phenol (Bray and Thorpe, 1954)}

The leaf samples from each treatment weighing one gram was taken and ground using a pestle and mortal in $10 \mathrm{ml}$ of $80 \%$ ethanol. The homogenate was centrifuged at $10,000 \mathrm{rpm}$ for $20 \mathrm{~min}$ and the supernant was saved. Then the residue was reextracted with five times the volume of $80 \%$ ethanol; the supernant was centrifuged, pooled and allowed to dry. The residue was dissolved in a known volume of distilled water. Different quantity of aliquot (0.2$2 \mathrm{ml}$ ) was taken in test tubes and made up to $3 \mathrm{ml}$ with distilled water for $1 \mathrm{~min}$. two $\mathrm{ml}$ of $20 \%$ of $\mathrm{Na}_{2} \mathrm{Co}_{3}$ solution was added to each tube. The contents were mixed thoroughly and the tubes were kept in boiling water for one min and cooled subsequently. Then, the absorbance reading was measured at $650 \mathrm{~nm}$ against a reagent blank in a spectrometer. Different concentrations of catechol were prepared and observed for drawing the standard curve.

\section{Estimation of Nitrogen (Humphries, 1956)}

\section{Digestion}

The leaf sample weighing $0.5 \mathrm{gm}$ was taken in $100 \mathrm{ml}$ conical flask and $10 \mathrm{ml}$ of diacid mixture was added. The flask was kept overnight and few drops of perchloric was added and digested over a sand bath till a clear solution was obtained. The solution was filtered using whatman no. 1 filter paper and the volume was made up to $100 \mathrm{ml}$

\section{Distillation}

Ten ml of the solution was taken in micro kjeldhal distillation flask and $10 \mathrm{ml}$ of 40 percent $\mathrm{NaOH}$ was added. Steam was allowed to pass through the sample, distillation off the ammonia into the flask containing boric acid and the indicator solution (20 $\mathrm{ml}$ boric acid) was mixed. Distillation of the sample was maintained for seven $\min$ and then the flask was lowered allowing the solution to drop from 
the condenser into the flask for about one min. The tip of the condenser outlet was washed with distilled water. The solution of boric acid and indicator containing the distilled off ammonia was titrated with standardized $\mathrm{HCl}$ or $\mathrm{H}_{2} \mathrm{SO}_{4}$ until appearance of wine red colour. From the titter value, $\mathrm{N}$ content present in the sample was calculated.

\section{Estimation of Phosporus (Jackson, 1973)}

Five $\mathrm{ml}$ of the titrated extract with the sample was taken into $250 \mathrm{ml}$ volumetric flask and five $\mathrm{ml}$ of Barton's reagent was added and shaken well. Then volume was made up to $25 \mathrm{ml}$ with distilled water and again shaken well. After $10 \mathrm{~min}$, the intensity yellow color developed was read in a colori-meter at a wavelength $470 \mathrm{~nm}$. The colorimeter reading was plotted in $\mathrm{x}$-axis (absorbance value) and concentration (ppm) in $y$-axis in a graph sheet. The concentration of $p$ in the test solution was estimated by referring to the standard curve.

\section{Estimation of Potassium (Toth and Prince, 1949)}

Series of potassium standards ranging from 0 to $100 \mathrm{ppm}$ was prepared and fed into a flame photometer through the atomizer. The readings of the galvanometer were plotted as a function of $\mathrm{k}$ concentration (in $\mathrm{ppm}$ ). Small quantity of the triacid extract (nitric acid, sulphuric acid and perchloric acid) in the ratio of 9:2:1 with the sample was transferred into a vial after neutralizing with dilute ammonia. Then the solution was fed into the flame photometer and the readings were noted. The concentration of $\mathrm{k}$ in the test solution was estimated by referring to the standard.

\section{Estimation of Sugars}

The quantity of reducing sugars (Nelson, 1944) and non-reducing sugars (Malhotra and Sarkar, 1979) in the fruits of the tomato accessions were estimated.

\section{Results and Discussion}

Various bio-physical factors operative in the accessions as influenced by selected microbial inoculants were studied. Among the biophysical factors, trichome density on the foliage was found to influence the insect preference. In the foliage of the selected tomato accessions, glandular and nonglandular trichomes were observed. Four type of trichomes such as, type I, monocellular base, type VI, a multicellular stalk with a 2-4 cellular glandular head and monocellular base and type VII a very short unicellular stalk with a 4-8 celled glandular head were detected in the leaves and petioles of accessions as influenced by selected microbial inoculants.

Data on density and types of trichomes present in the adaxial leaf surface of the accessions as influenced by microbial inoculants are presented in (Table 1). The accessions Varushanadu Local had the maximum number of all types of trichomes irrespective of the treatments. Among the treatments, Pseudomonas + K-solubilizer (T9) treated plants had the maximum number of trichomes in both accessions. This was followed by plants nourished with $\mathrm{K}$-solubilizer in case of both the accessions. Among the types of trichomes, number of Types I and IV trichomes were the maximum in the plants nourished with Pseudomonas + K-solubilizer (T9).

Type VI trichomes were predominant in the plants treated with Pseudomonas $+\mathrm{K}$ solubilizer (T9) followed by K-solubilizer (T4) applied plants of the both accessions. Type VII trichomes was maximum in Pseudomonas $\quad+$ K-solubilizer nourished plants. 
Table.1 Trichome density on the adaxial leaf surface of the tomato accessions as influenced by selected bioinoculants

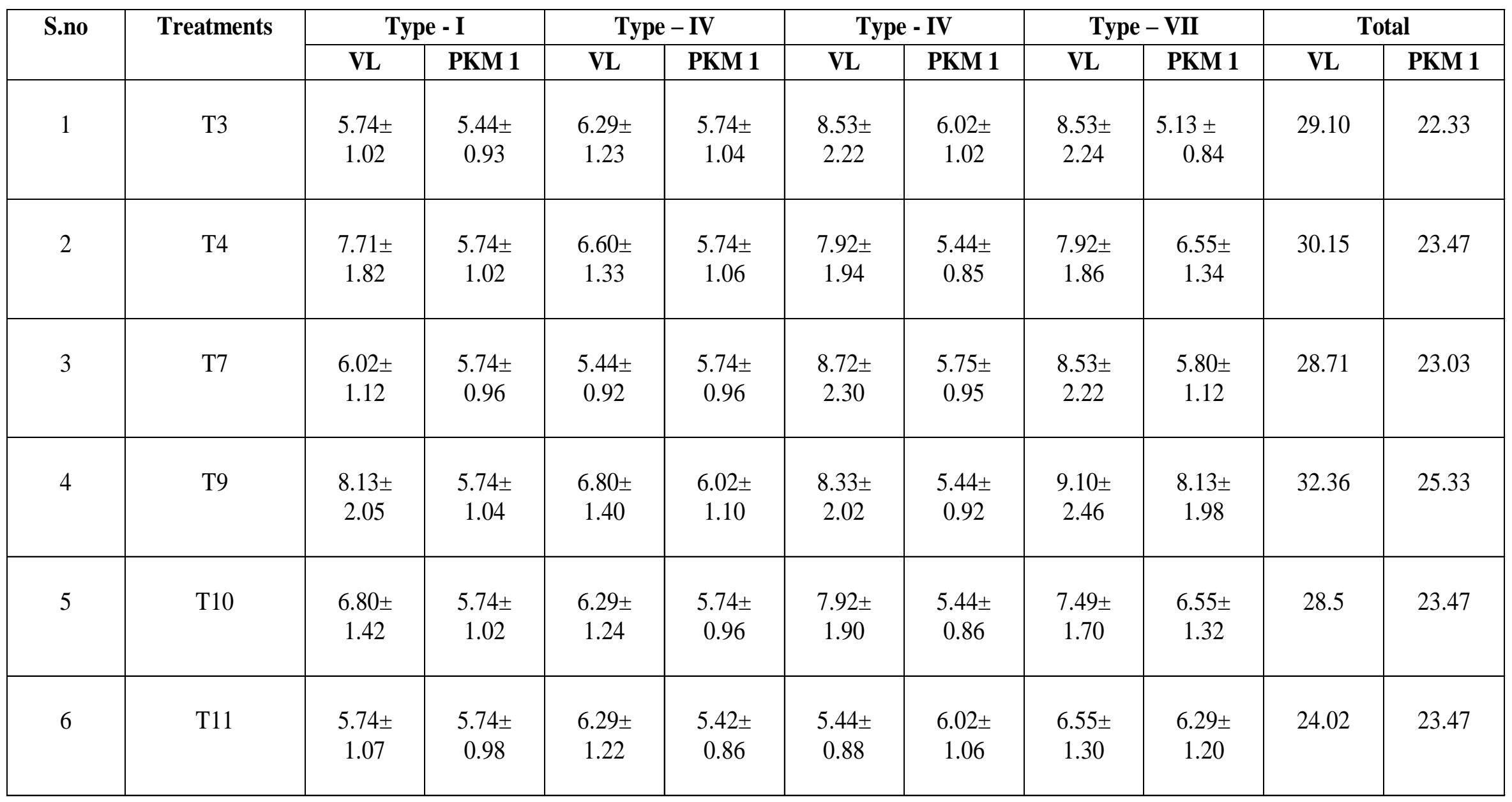

Each value is a mean of five replications

Mean values followed by standard error 
Table 2. Trichome density on the abaxial leaf surface of the tomato accessions as influenced by selected bioinoculants

\begin{tabular}{|c|c|c|c|c|c|c|c|c|c|c|c|}
\hline \multirow[t]{2}{*}{ S. no } & \multirow[t]{2}{*}{ Treatments } & \multicolumn{2}{|c|}{ Type - I } & \multicolumn{2}{|c|}{ Type-IV } & \multicolumn{2}{|c|}{ Type - IV } & \multicolumn{2}{|c|}{ Type - VII } & \multicolumn{2}{|c|}{ Total } \\
\hline & & VL & PKM 1 & VL & PKM 1 & VL & PKM 1 & $\mathbf{V L}$ & PKM 1 & $\begin{array}{l}\mathbf{V L} \\
\end{array}$ & PKM 1 \\
\hline 1 & $\mathrm{~T} 3$ & $\begin{array}{l}8.13 \pm \\
1.96\end{array}$ & $\begin{array}{c}6.29 \pm \\
1.18\end{array}$ & $\begin{array}{c}6.29 \pm \\
1.21\end{array}$ & $\begin{array}{c}8.13 \pm \\
2.09\end{array}$ & $\begin{array}{c}8.13 \pm \\
1.99\end{array}$ & $\begin{array}{c}5.74 \pm \\
1.03\end{array}$ & $\begin{array}{c}6.55 \pm \\
1.31\end{array}$ & $\begin{array}{c}5.74 \pm \\
1.03\end{array}$ & 29.11 & 25.9 \\
\hline 2 & $\mathrm{~T} 4$ & $\begin{array}{c}8.13 \pm \\
2.02\end{array}$ & $\begin{array}{c}6.55 \pm \\
1.34\end{array}$ & $\begin{array}{c}8.91 \pm \\
2.43\end{array}$ & $\begin{array}{c}6.55 \pm \\
1.33\end{array}$ & $\begin{array}{c}6.80 \pm \\
1.37\end{array}$ & $\begin{array}{c}5.44 \pm \\
0.93\end{array}$ & $\begin{array}{c}6.55 \pm \\
1.33\end{array}$ & $\begin{array}{c}5.44 \pm \\
0.93\end{array}$ & 30.39 & 23.98 \\
\hline 3 & $\mathrm{~T} 7$ & $\begin{array}{c}8.13 \pm \\
1.98\end{array}$ & $\begin{array}{c}6.29 \pm \\
1.20\end{array}$ & $\begin{array}{c}8.72 \pm \\
2.36\end{array}$ & $\begin{array}{c}8.19 \pm \\
2.37\end{array}$ & $\begin{array}{c}7.92 \pm \\
1.93\end{array}$ & $\begin{array}{c}5.74 \pm \\
0.98\end{array}$ & $\begin{array}{c}7.04 \pm \\
1.46\end{array}$ & $\begin{array}{c}7.04 \pm \\
1.46\end{array}$ & 31.81 & 27.26 \\
\hline 4 & T9 & $\begin{array}{c}8.72 \pm \\
2.32\end{array}$ & $\begin{array}{c}7.92 \pm \\
1.89\end{array}$ & $\begin{array}{c}9.10 \pm \\
2.47\end{array}$ & $\begin{array}{c}7.92 \pm \\
1.87\end{array}$ & $\begin{array}{c}8.72 \pm \\
2.33\end{array}$ & $\begin{array}{c}5.44 \pm \\
0.89\end{array}$ & $\begin{array}{c}7.49 \pm \\
1.66\end{array}$ & $\begin{array}{c}5.74 \pm \\
0.96\end{array}$ & 34.03 & 27.02 \\
\hline 5 & $\mathrm{~T} 10$ & $\begin{array}{c}8.13 \pm \\
2.00\end{array}$ & $\begin{array}{c}6.29 \pm \\
1.19\end{array}$ & $\begin{array}{c}9.10 \pm \\
2.53\end{array}$ & $\begin{array}{c}6.29 \pm \\
1.24\end{array}$ & $\begin{array}{c}5.44 \pm \\
0.88\end{array}$ & $\begin{array}{c}5.44 \pm \\
1.06\end{array}$ & $\begin{array}{c}6.29 \pm \\
1.22\end{array}$ & $\begin{array}{c}5.74 \pm \\
0.99\end{array}$ & 28.96 & 33.44 \\
\hline 6 & $\mathrm{~T} 11$ & $\begin{array}{c}7.92 \pm \\
1.88\end{array}$ & $\begin{array}{l}6.29 \pm \\
1.23\end{array}$ & $\begin{array}{c}8.13 \pm \\
2.04\end{array}$ & $\begin{array}{c}6.29 \pm \\
1.17\end{array}$ & $\begin{array}{c}6.80 \pm \\
1.37\end{array}$ & $\begin{array}{c}5.74 \pm \\
0.99\end{array}$ & $\begin{array}{c}7.49 \pm \\
1.16\end{array}$ & $\begin{array}{c}5.44 \pm \\
0.88\end{array}$ & 30.34 & 23.76 \\
\hline
\end{tabular}

Each value is a mean of five replications Mean values followed by standard error 
Table 3. Trichome on the petiole of the tomato accessions as influenced by selected bioinoculants

\begin{tabular}{|c|c|c|c|c|c|c|c|c|c|c|c|}
\hline \multirow[t]{2}{*}{ S. no } & \multirow[t]{2}{*}{ Treatments } & \multicolumn{2}{|c|}{ Type - I } & \multicolumn{2}{|c|}{ Type - IV } & \multicolumn{2}{|c|}{ Type - IV } & \multicolumn{2}{|c|}{ Type - VII } & \multicolumn{2}{|c|}{ Total } \\
\hline & & $\mathbf{V L}$ & PKM 1 & $\mathbf{V L}$ & PKM 1 & VL & PKM 1 & VL & PKM 1 & VL & PKM 1 \\
\hline 1 & $\mathrm{~T} 3$ & $\begin{array}{c}8.13 \pm \\
2.00\end{array}$ & $\begin{array}{c}7.49 \pm \\
1.71\end{array}$ & $\begin{array}{c}7.13 \pm \\
2.03\end{array}$ & $\begin{array}{c}7.71 \pm \\
1.74\end{array}$ & $\begin{array}{c}6.72 \pm \\
2.32\end{array}$ & $\begin{array}{c}6.80 \pm \\
1.42\end{array}$ & $\begin{array}{c}8.13 \pm \\
1.99\end{array}$ & $\begin{array}{c}7.92 \pm \\
1.78\end{array}$ & 30.11 & 29.92 \\
\hline 2 & $\mathrm{~T} 4$ & $\begin{array}{c}8.72 \pm \\
2.27\end{array}$ & $\begin{array}{c}7.92 \pm \\
1.84\end{array}$ & $\begin{array}{c}8.53 \pm \\
2.22\end{array}$ & $\begin{array}{c}7.71 \pm \\
1.80\end{array}$ & $\begin{array}{c}8.91 \pm \\
2.42\end{array}$ & $\begin{array}{c}7.71 \pm \\
1.84\end{array}$ & $\begin{array}{c}8.13 \pm \\
2.02\end{array}$ & $\begin{array}{c}7.92 \pm \\
1.94\end{array}$ & 34.08 & 31.26 \\
\hline 3 & $\mathrm{~T} 7$ & $\begin{array}{c}8.13 \pm \\
2.03\end{array}$ & $\begin{array}{c}8.13 \pm \\
1.96\end{array}$ & $\begin{array}{c}8.13 \pm \\
2.00\end{array}$ & $\begin{array}{c}7.04 \pm \\
1.54\end{array}$ & $\begin{array}{c}8.91 \pm \\
2.40\end{array}$ & $\begin{array}{c}6.80 \pm \\
1.44\end{array}$ & $\begin{array}{c}7.92 \pm \\
1.96\end{array}$ & $\begin{array}{c}7.92 \pm \\
1.94\end{array}$ & 33.10 & 29.89 \\
\hline 4 & T9 & $\begin{array}{c}8.72 \pm \\
2.33\end{array}$ & $\begin{array}{c}8.13 \pm \\
1.98\end{array}$ & $\begin{array}{c}8.91 \pm \\
2.43\end{array}$ & $\begin{array}{c}7.27 \pm \\
1.57\end{array}$ & $\begin{array}{c}9.10 \pm \\
2.53\end{array}$ & $\begin{array}{c}7.27 \pm \\
1.54\end{array}$ & $\begin{array}{c}8.13 \pm \\
2.06\end{array}$ & $\begin{array}{c}7.92 \pm \\
1.88\end{array}$ & 34.86 & 28.63 \\
\hline 5 & $\mathrm{~T} 10$ & $\begin{array}{c}8.33 \pm \\
2.14\end{array}$ & $\begin{array}{c}7.71 \pm \\
1.73\end{array}$ & $\begin{array}{c}8.72 \pm \\
2.32\end{array}$ & $\begin{array}{c}7.71 \pm \\
1.79\end{array}$ & $\begin{array}{c}8.91 \pm \\
2.44\end{array}$ & $\begin{array}{c}7.49 \pm \\
1.60\end{array}$ & $\begin{array}{c}7.71 \pm \\
1.80\end{array}$ & $\begin{array}{c}5.74 \pm \\
1.02\end{array}$ & 33.67 & 28.65 \\
\hline 6 & $\mathrm{~T} 11$ & $\begin{array}{c}8.53 \pm \\
2.19\end{array}$ & $\begin{array}{c}7.92 \pm \\
1.87\end{array}$ & $\begin{array}{c}8.72 \pm \\
2.34\end{array}$ & $\begin{array}{c}7.71 \pm \\
1.80\end{array}$ & $\begin{array}{c}9.98 \pm \\
2.96\end{array}$ & $\begin{array}{c}7.71 \pm \\
1.76\end{array}$ & $\begin{array}{c}7.71 \pm \\
1.82\end{array}$ & $\begin{array}{c}8.13 \pm \\
1.96\end{array}$ & 34.94 & 31.47 \\
\hline
\end{tabular}

Each value is a mean of five replications Mean values followed by standard error 
Table 4. Biophysical factors of the selected tomato accessions as influenced by bioinoculants

\begin{tabular}{|c|c|c|c|c|c|c|c|c|c|}
\hline \multirow[t]{2}{*}{ S. no } & \multirow[t]{2}{*}{ Treatments } & \multicolumn{2}{|c|}{ Leaf length(cm) } & \multicolumn{2}{|c|}{ Leaf breath $(\mathbf{c m})$} & \multicolumn{2}{|c|}{ Petiole length $(\mathrm{cm})$} & \multicolumn{2}{|c|}{ Leaf angle $(\mathrm{cm})$} \\
\hline & & VL & PKM 1 & VL & PKM 1 & VL & PKM 1 & VL & PKM 1 \\
\hline 1 & T3 & $5.08 \pm 0.44$ & $4.80 \pm 0.31$ & $3.94 \pm 0.40$ & $2.96 \pm 0.62$ & $7.22 \pm 0.22$ & $5.78 \pm 0.56$ & $72.55 \pm 3.92$ & $96.65 \pm 4.02$ \\
\hline 2 & $\mathrm{~T} 4$ & $5.22 \pm 0.43$ & $5.14 \pm 0.33$ & $3.33 \pm 0.44$ & $2.64 \pm 0.32$ & $6.86 \pm 0.36$ & $5.79 \pm 0.42$ & $67.39 \pm 3.27$ & $97.02 \pm 4.06$ \\
\hline 3 & $\mathrm{~T} 7$ & $5.14 \pm 0.23$ & $5.12 \pm 0.29$ & $3.28 \pm 0.29$ & $2.86 \pm 0.36$ & $7.45 \pm 0.33$ & $5.00 \pm 0.80$ & $82.62 \pm 3.22$ & $97.62 \pm 4.10$ \\
\hline 4 & T9 & $5.30 \pm 0.32$ & $5.52 \pm 0.27$ & $3.17 \pm 0.32$ & $2.84 \pm 0.52$ & $7.77 \pm 0.27$ & $5.92 \pm 0.32$ & $72.06 \pm 3.56$ & $92.32 \pm 3.88$ \\
\hline 5 & $\mathrm{~T} 10$ & $5.02 \pm 0.36$ & $5.16 \pm 0.26$ & $3.32 \pm 0.27$ & $5.52 \pm 0.44$ & $7.89 \pm 0.26$ & $4.98 \pm 0.82$ & $76.35 \pm 4.02$ & $82.26 \pm 3.96$ \\
\hline 6 & $\mathrm{~T} 11$ & $5.10 \pm 0.44$ & $5.20 \pm 0.30$ & $3.52 \pm 0.56$ & $3.21 \pm 0.66$ & $7.40 \pm 0.56$ & $4.13 \pm 0.47$ & $60.32 \pm 3.92$ & $92.26 \pm 3.68$ \\
\hline
\end{tabular}

Each value is a mean of five replications Mean values followed by standard error 
Table 5. Biochemical factors of the tomato accessions as influenced by bioinoculants

\begin{tabular}{|c|c|c|c|c|c|c|c|c|c|c|c|c|c|}
\hline \multirow[t]{3}{*}{ S.no } & \multirow[t]{3}{*}{ Treatments } & \multirow{2}{*}{\multicolumn{2}{|c|}{ Phenol mg/g }} & \multirow{2}{*}{\multicolumn{2}{|c|}{$\begin{array}{c}\text { Nitrogen } \\
(\%)\end{array}$}} & \multirow{2}{*}{\multicolumn{2}{|c|}{ Phosphorous (\%) }} & \multirow{2}{*}{\multicolumn{2}{|c|}{$\begin{array}{c}\text { Potash } \\
(\%)\end{array}$}} & \multicolumn{4}{|c|}{ Sugars(mg/g) } \\
\hline & & & & & & & & & & & & Non & ucing \\
\hline & & VL & PKM & VL & PKM & VL & PKM & VL & PKM & VL & PKM & VL & PKM \\
\hline 1 & $\mathrm{~T} 3$ & 0.332 & 0.315 & 8.43 & 8.50 & 0.75 & 0.72 & 5.09 & 5.03 & 4.19 & 4.21 & 2.04 & 2.06 \\
\hline 2 & $\mathrm{~T} 4$ & 0.352 & 0.325 & 8.37 & 8.28 & 0.73 & 0.62 & 5.22 & 5.12 & 4.03 & 4.10 & 2.02 & 2.08 \\
\hline 3 & $\mathrm{~T} 7$ & 0.337 & 0.317 & 8.41 & 8.30 & 0.83 & 0.85 & 5.12 & 5.06 & 4.08 & 4.12 & 1.98 & 2.12 \\
\hline 4 & T9 & 0.356 & 0.327 & 8.43 & 8.40 & 0.86 & 0.93 & .24 & 5.13 & 4.04 & 4.14 & 2.10 & 2.24 \\
\hline 5 & $\mathrm{~T} 10$ & 0.346 & 0.321 & 8.57 & 8.42 & 0.74 & 0.62 & 4.81 & 5.08 & 4.17 & 4.09 & 2.09 & 2.18 \\
\hline 6 & $\mathrm{~T} 11$ & 0.302 & 0.306 & 6.13 & 6.12 & 0.62 & 0.55 & 4.93 & 4.88 & 4.00 & 4.03 & 1.49 & 1.58 \\
\hline
\end{tabular}

Each value is a mean of five replications 
On the abaxial leaf surface of the accession, number of Type I trichomes was the maximum in plants of the accession Varushanadu Local nourished with Pseudomonas + K-solubilizer (T9). Type IV trichomes were more on Pseudomonas $+\mathrm{K}$ solubilizer (T9) treated plants. The number of glandular trichomes, Type VI was the maximum in plants of both accessions as influenced by Pseudomonas + K-solubilizer (T9) followed by nourished plants of Varushanadu Local. Type VII trichome was maximum in Pseudomonas $+\mathrm{K}$-solubilizer (T9) nourished plants of Varushanadu Local (Table 2).

With regard to the density the trichomes on the petiole, type I and type IV trichomes were more predominant in the plants supplied with Pseudomonas $+\mathrm{K}$-solubilizer (T9). The glandular types, type VI and type VII trichomes were the maximum in plants of Varushanadu Local treated with Pseudomonas + K-solubilizer (T9) followed by K-solubilizer(T4) supplied plants (Table 3). Similarly, Juvik et al. (1994) proved that the presence of high level of toxic acyl sugars in glandular trichomes exudates play a major role in the resistance of Lycopessicon pennelii to tomato fruit worm Helicoverpa zea Boddie. The phenol and chlorogenic acid in the leaf lamella and tips of glandular trichomes account for over 60 per cent of the total phenol content of tomato (Isman and Duffey, 1982)

Among the other biophysical factors, leaves were longer and broader in PKM1 and Varushanadu Local plants respectively. Among the selected microbial inoculants, Pseudomonas + K-solubilizer (T9) combination nourished plants had longer and broader leaves. Petiole length was the maximum in the Varushanadu Local plants treated with Pseudomonas + K-solubilizer. The angle of leaf to the stem was higher in
PKM1 plants irrespective of treatments (Table 4).

Biochemical contents of foliage of plants have direct impact on the insect attraction and its subsequent infestation (Ananthakrishnan, 1996). Phenol content of the foliage was the maximum (0.356) in Pseudomonas + K-solubilizer (T9) nourished plants followed by K-solubilizer (T4) applied plants of both accessions. The control plants (without treatment) contained less amount (0.302) of phenol. Regarding nitrogen and content of the foliage, the phosphobacteria + K-solubilizer (T10) applied plants had the minimum quantity, whereas Pseudomonas $+\mathrm{k}$ - solublizer contents were maximum in plants of Varushanadu Local treated with phosphobacteria + K-solubilizer (T4). Reducing \& Non-Reducing sugar concentrations were the maximum in the Pseudomonas treated plants of both accessions (Table5).

Similar to the present findings, biochemical contents of the tomato such as non-reducing sugar and phenols present in higher quantities were found negatively correlated with fruit worm $H$. armigera infestation (Selvanarayanan, 2000; Dhakshinamoorthy, 2002; Selvanarayanan and Narayanasamy, 2006). Further, phenol content was higher in resistant accession and it exerted a significant negative correlation with larval feeding (Gopalakrishnan, 2006). Phenol, non reducing sugar and $\mathrm{K}$ contents were found negatively correlated with leaf caterpillar Spodoptera litura Fab. Incidence in tomato (Muthukumaran, 2004).

It is concluded from the present investigation that Pseudomonas $+\mathrm{K}-$ solubilizer (T9) nourished plants had higher biochemical and biophsical factors of resistance against $H$. armigera. But, more in 
depth and also repeated field and glasshouse evaluations of the combination of the above promising microbial inoculants to enhance the resistance without compromising the yield traits can be conducted.

\section{References}

Ananthakrishnan, T.N. 1996. Biotechnological Perspectives in Chemical Ecology of Insects. Oxford and IBH publishing Co. Pvt. Ltd., New Delhi, pp. 225.

Armes, N.J., Bond, G.S., Cooter, R.J. 1992. The laboratory culture and development of Helicoverpa armigera. Natural resources institute Bulletin No.57, Chatham, United Kingdom, pp. 22.

Bray, H.G., Thorpe, W.V. 1954. Analysis of phenolic compounds of interest in metabolism. Meth. Biochem. Anal., 1: 2752.

Dhakshinamoorthy, G. 2002. Studies on resistance of tomato against fruit borer, Helicoverpa armigera (Hubner). M.Sc. (Ag.) Thesis, Annamalai University. India.

Gopalakrishnan, R. 2006. Induced resistance in tomato against key insect pests. M.Sc. (Ag.) Thesis. Annamalai University. India. pp. 146.

Humphries, E.C.1956. Mineral components and ash analysis. Modern Methods of Plant Anal. Springer verlag, Berlin. pp. 468502.

Isman, M.B., Duffey, S.S. 1982. Phenolic compounds in foliage of commercial tomato cultivars as growth inhibitors to the fruit worm, Heliothis zea. J. Amer. Soc. Hort. Sci., 107: 167-170

Jackson, M.L. 1973. Soil chemical analysis. Prentice Hall of India Pvt. Ltd., New Delhi.

Juvik, J.A., Shapiro, J.A., Young, T.E.,

\section{How to cite this article:}

N. Muthukumaran. 2016. Biophysical and Biochemical Factors of Resistance in Tomato Accessions as Influenced by Selected Bioinoculants against Fruit worm Helicoverpa armigera (Hubner). Int.J.Curr.Microbiol.App.Sci. 5(1): 252-262.

http://dx.doi.org/10.20546/ijcmas.2016.501.024
Mutschler, M.A. 1994. Acylglucoses from wild tomatoes alter behavior and reduce growth and survival of Helicoverpa zea and Spodoptera exigua (Lepidoptera: Noctuidae). J. Econ. Entomol., 87: 482-492.

Malhotra, S.S., Sarkar, S.K. 1979. Effects of sulphur dioxide on sugar and free amino acid content of pine seedlings. Physiol. Plant Pathol., 47: 223-228.

Muthukumaran, N. 2004. Resistance of Lycopersicon accessions and their hybrid derivatives against certain insect pests. $M$. Sc. (Ag.) Thesis, Annamalai University, India. pp.122.

Muthukumaran, N., Selvanarayanan, V. 2010. Differential reaction of hybrid derivatives of Lycopersicon accessions against whitefly Bemisia tabaci Genn. in South India. Pp. 235-238. In: Ignacimuthu, S.J and B.V. David (Eds.) Non-chemical Insect Pest Management, Elite Publishing House Pvt. Ltd., New Delhi, India. pp. 266.

Nelson, N. 1944. A photometric adaptation of the somogyi method for the determination of glucose. J. Biol. Chem., 153: 375-380.

Selvanarayanan, V. 2000. Host Plant resistance in tomato against fruit borer, Helicoverpa armigera (Hubner). Ph.D. Thesis, Annamalai University, India. pp. 251.

Selvanarayanan, V., Narayanasamy, P. 2006. Factors of resistance in tomato accessions against the fruit worm Helicoverpa armigera (Hubner). Crop Prot., 256(25): 1075-1079.

Toth, S.J., Prince, A.L. 1949. Estimation of cation exchange capacity and exchangeable calcium, potassium and sodium contents of soil by flame photometer. Soli Sci., 67: 439-445. 